\title{
ДЕЯКІ АСПЕКТИ ПРОВЕДЕННЯ МОДУЛЬНОГО КОНТРОЛЮ 3 НОВОЇ ДИСЦИПЛІНИ “МОНІТОРИНГ ЛІКАРСЬКИХ ПРЕПАРАТІВ” У МАГІСТРІВ-ЛАБОРАНТІВ ЗА ДОПОМОГОЮ ТЕЛЕКОМУНІКАЦІЙНИХ ТЕХНОЛОГІЙ
}

\author{
І. Ф. Бєленічев, Н. В. Бухтіярова, С. А. Моргунцова \\ Запорізький державний медичний університет
}

\section{SOME ASPECTS OF MODULE CONTROL ON NEW SUBJECT "REMEDIES MONITORING" IN MASTERS-LABORATORIANS WITH THE HELP OF TELECOMMUNICATION TECHNOLOGIES}

\author{
I. F. Bielenichev, N. V. Bukhtiyarova, S. A. Morhuntsova \\ Zaporizhian State Medical University
}

\begin{abstract}
Застосування в навчальному процесі телекомунікаційних технологій дозволить значно збільшити об'см знань 3 предмета “Моніторинг ліків”, які необхідні для магістрів-лаборантів. Ці навчальні технології дозволять вже на початковому етапі навчання виявити вихідний рівень знань магістра з базових медико-біологічних та спеціальних дисциплін, визначити його ступінь готовності до навчання і здатність як індивідуума сприймати матеріал і підвищити ефективність засвоєння корисної інформації з основних аспектів даної дисципліни i, як результат, підвищити якісну успішність магістрів.

Use of telecommunication technologies in teaching process give the possibilities to enlarge knowledge on subject "Remedies monitoring" which are necessary for masters-laboratorians. Such educative technologies allow to reveal initial level of masters' knowledge on the main medico-biological and special subjects on initial stage, to define their preparedness for learning and ability as individual to apprehend material and increase efficiency of learning of useful information of main aspects of the subject and as the result to increase masters' qualitative learning efficiency.
\end{abstract}

Вступ. На сучасному етапі телекомунікаційні технології (ТT) знайшли широке застосування у медичній вищій школі і особливо у такому новому напрямі медичної освіти, як процес навчання магістрів за спеціальністю “Лабораторна діагностика". Теленавчання дозволяє здійснити контакт з віддаленою аудиторією, забезпечує швидкість передавання інформації. ТТ збільшує обсяг знань, що необхідні для підготовки магістрів-лаборантів. Зазначені навчальні технології дозволяють суттєво зменшити просторово-часові обмеження в педагогічному процесі при односторонньому збільшенні обсягу знань. Крім того, TT дозволить вже на початковому етапі навчання виявити початковий рівень знань магістра 3 базових медико-біологічних і спеціальних дисциплін, визначити ступінь його готовності до навчання та здатність як особистості сприймати матеріал.

Все це дозволить, використовуючи унікальні можливості ТТ, підвищити ефективність засвоєння корисної інформаціїз головних аспектів даної дисципліни підходів до визначення параметрів фармакокінетики лікарських препаратів, проведення моделювання фармакокінетичних процесів, використання принци- пу індивідуального дозування препаратів, розрахунків широти терапевтичної дії та показників безпеки фармакотерапії, i, в кінцевому результаті, підвищить якісну успішність магістрів.

Основна частина. Головною ланкою, що визначає ефективність ТТ, є кінцева оцінка успішності магістрів, тобто проведення іспиту або модульного контролю. В традиційному випадку концептуальний підхід до такої оцінки полягає у методичній обробці представленого викладачем матеріалу таким чином, щоб виділити найбільш суттєві з загальноприйнятої точки зору питання. 3 даних питань надалі формуються екзаменаційні задачі (розрахунок гострої токсичності, видової та статевої чутливості до лікарських препаратів, визначення їх головних фармакокінетичних параметрів, визначення специфічних лабораторно - біохімічних маркерів токсичності лікарських препаратів) та тестові завдання. Але подібна форма іспиту потребує присутності всіх магістрів в одному місці одночасно, наявності комп'ютерного класу чи великої кількості тестових завдань на паперових носіях. Тестові завдання є дуже конкретизованими і вводять обмеження на внутрішні

(ㄱ І. Ф. Бєленічев, Н. В. Бухтіярова, С. А. Моргунцова 
смислові нюанси і численні тематичні перехрещення в інформаційній галузі, яка підлягає розгляду. Це не дозволяє мати об' єктивну оцінку знань магістра 3 даної досить складної дисципліни, яка базується на знаннях фармакології, токсикології, патології, біохімії та лабораторної діагностики.

Таким чином, для підвищення ефективності викладання дисципліни “Моніторинг лікарських засобів” необхідно модифікувати процес навчання, до того ж зміни повинні торкнутися, перш за все, кінцевої оцінки успішності.

На наш погляд, рішенням проблеми може бути запровадження ТТ на етапі проведення іспиту. Маємо думку, що рішення даного питання може йти двома шляхами.

По-перше, необхідно проводити попереднє тестування магістрів за всіма темами, що вивчаються ними і стосуються знань $з$ фармакології, токсикології, патології, біохімії, що дозволить враховувати початковий освітній рівень магістра, його професійну підготовку, а також дозволить визначити “сильні” та “слабкі” групи на курсі. Для цього необхідно скласти тестові завдання, що охоплюють особливості фармакокінетики лікарських препаратів, перебіг фармакокінетичних процесів при різних патологічних станах, підходи індивідуального дозування препаратів, розрахунки широти терапевтичної дії і показники безпеки фармакотерапії, а також знання про побічну дію лікарських препаратів, їх взаємодії з алкоголем та міри профілактики даних реакцій, загальні фармакологічні характеристики головних лікарських препаратів, які рекомендовано для обов'язкового вивчення. Необхідно застосовувати різні способи тестування (прості і ускладнені збірники, системи множинної вибірки, тематичні реферати, контрольні роботи, телеконсультаційні завдання). Це дозволить ще до проведення модульного контролю визначити загальний рівень курсу з даної дисципліни. Якщо в окремих магістрів буде виявлено незадовільні знання до модульного контролю, у такому випадку цим магістрам електронною поштою буде надіслано навчальні тести, які дозволяють отримати варіант правильної відповіді та пояснення до нього. В деяких випадках магістр, зареєструвавшись, може пройти попереднє тестування у режими on-line i отримати свій результат. При використанні ТТ в даному напрямі іспит у магістрів необхідно буде проводити у формі тестування з використанням тестових завдань другого та третього рівнів важкості. Використання провіднико- вих технологій дозволяє здійснити таке тестування в двох варіантах: відкладене (FTP-сервер, електронна пошта) та пряме (Web-сервер, режим відеоконференціi).

По-друге, використання ТТ дозволяє провести таку форму модульного контролю, як відеоіспит. Відеоіспит передбачає двостронній аудіовізуальний контакт з магістрами і повинен проходити у спеціальному приміщенні при наявності не менш ніж двох відеокамер і декількох мікрофонів на робочих місцях. Магістр може знаходитися на робочому місті у будь-якому регіоні як України, так і країн СНД чи дальнього зарубіжжя. Дана система дозволить провести кінцеву (екзаменаційну) оцінку знань тих магістрів, які з будьяких причин не змогли прибути на сесію. Відеоіспит проводиться після попередньої реєстрації магістра та дозволить зберегти запис іспиту на випадок необхідності вирішення спірного питання. Магістр, який складає іспит, повинен бути завжди один на один з монітором, тоді як у віддалених екзаменаторів їх повинно бути не менше двох. У процесі підготовки до іспиту бажано використовувати інструментальний та технічний захист інформації, що передається та отримується.

Для відеоіспиту абсолютно неприйнятний режим очної телемедичної консультації. Для телемедичної консультації характерна рівноцінність потоків інформації від особи, яка консультується, до консультанта та навпаки. Під час відеоіспиту цей потік головним чином спрямований від магістра до викладача. Екзаменатор постає у ролі ініціатора потоку інформації, тобто є перманентно присутнім на іспиті, поводить себе дискретно. У ідеальному випадку відеоіспит повинен являти собою роботу магістра з гнучкою базою даних, що здатна змінюватися у будь-який проміжок часу та такою, що знаходиться під постійним спостереженням екзаменатора.

Висновки. Застосування в навчальному процесі телекомунікаційних технологій дозволить значно збільшити об'єм знань з предмета “Моніторинг ліків”, які необхідні для магістрів-лаборантів. Ці навчальні технології дозволять вже на початковому етапі навчання виявити вихідний рівень знань магістра з базових медико-біологічних та спеціальних дисциплін, визначити його ступінь готовності до навчання i здатність як індивідуума сприймати матеріал і підвищити ефективність засвоєння корисної інформації 3 основних аспектів даної дисципліни i, як результат, підвищити якісну успішність магістрів. 


\section{Лiтература}

1. Посібник для самостійної роботи студентів заочного відділення фармацевтичного факультету (дистанційна форма навчання / [I. С. Чекман, І. Ф. Бєленічев, Н. О. Горчакова та ін.]. - Київ, 2009. -154 с.

2. Пидаев А. В. Болонский процесс в Европе / А. В. Пидаев, В. Г. Передерий. - Киев, 2004. - 192 с.

3. Сборник обучающих тестов по фармакологии / под ред.
И. Ф. Беленичева. -Запорожье : Изд-во ЗГМУ, 2007. - 190 с. 4. Лицензирование в Европейском Союзе : фармацевтический сектор / под ред. В. А. Ксенко. - Киев : МОРИОН, 1998.-384 c.

5. Побічні реакції серцево-судинних засобів / I. С. Чекман, Н. О. Горчакова, І. Ф. Бєленічев, Н. В. Бухтіярова. Київ, 2010.-83 с. 